\title{
ON \\ DA BUSCA À CONQUISTA DA FELICIDADE
}

\section{Omar da Rosa Santos}

Membro Titular, Academia Nacional de Medicina

"Disce, puer, virtutem ex me verumque laborem"...

- E assim te vi crescer como homem para a vida...

Se te falta algo, ou se te sentes fraco porém,

cogita, pensa, descobre em ti a alma esquecida!

Tenho repetido: "o pior ingrato é o que esquece", mais que o que nega o benefício... ou, que dissimula...

- Se te fogem o ânimo e a força... o que fenece...

...De pé! - Porque choras? - Eia! Tua fé te estimula.
Teu mal é tristeza que devora: melancolia!

[sabes que dizem que a cura está na farmacopéia]

- Qual nada! - Em ti é a cura; na fonte que te nutria!

Recorda! Póe-te a nu e recorre à Teodicéia...

Tudo jaz na biblioteca da tua memória,

ou ainda no antigo mapa da tua viagem pelos chãos desta Terra: nave da tua história...

Lá vive o puro agasalho... velha mensagem... 
De novo no reconforto...

Reconcilia-te!

Contigo e co'o mundo... e rápido te venha o alento...

E, quando o amargo pesar vier... então ria-te!

Livras-te do mal e lança a amargura ao vento!

$\mathrm{Na}$ calma do lar... na alegria do olhar da criança,

e nos catalectos, dos mais simples aos mais profundos,

que o Criador envolva-te o espírito na lembrança,

na palinódia do peregrino, em poucos segundos!
Conserva teu livre arbítrio e sobrevive em paz...

Desfruta, na tua sina, a beleza da piedade...

-Vai! Por ti, hás de caminhar... só porque és capaz!

Por tanto, puer, alcançarás a Felicidade!

Suporta, com esperança, o que a Fortuna te traz

Nil admirari! - E, na Providência, persevera...

No tranquilo descanso, a serenidade que apraz.

- Serenidade! Liberdade!... “libertas quae sera..." 